of computational linguistics for the first time would find this book a pleasant and useful introduction to some of the tricks of the trade. Simple accounts are given of the more straightforward parsing algorithms at present in use, of suitable techniques for establishing and maintaining large computer dictionaries, and also of such loosely related aspects of language data-processing as concord. ance-making and on-line indexing and abstracting. $\mathrm{Mr}$ Hays's RAND Corporation background occasionally obtrudes (does any other group of linguists really care, for instance, that line-printers can't usually produce italic or bold-face letters?) but on the whole, and always with the limitations already mentioned, his book is a very fair introduction to some main areas of present day work.

Paul Bratley

\section{EARLY ASTRONOMER}

\section{John Kepler}

By Angus Armitage. Pp. $194+4$ plates. (London: Faber and Faber Ltd., 1966.) 21s. net

KrPLER's life and work present the most difficult prob. lems of narrative and interpretation for a modern biographer. The work he did was strongly shaped by his personal and professional affairs, which were conducted in a provincial corner of Central Europe, then torn by religious dissension and eventually by the Thirty Years' War. Also, his personal style of work is extremely difficult for us to grasp; the intimate combination of a speculative mathematical-religious mysticism with painstaking and self-critical research is foreign to our experience of either "science" or "mysticism".

In this brief and elementary biography, Dr Armitage succeeds in overcoming most of these difficulties. The political and religious background to Kepler's environment is sketched in just sufficient detail to make it comprehensible; and the "neo-Platonic" aspect of Kepler's thought is presented clearly and with a minimum of apology. The technical side of his astronomical and mathematical work is popularized well, although the description of the classic study of the orbit of Mars relies rather too heavily on older sources, and ignores the recent studies which exhibit Kepler's "seventy trials" of a circular orbit as an iteration procedure intended to yield an approximation solution. For the assessment of Kepler's place in the history of science, the safe course is to stick to the later use of the "Three Laws" up to their re-statement in Newton's grand synthesis. This is Dr Armitage's approach. But from this we achieve no perspective on the tradition out of which Kepler's peculiar style and choice of problems rose, nor of the milieu in which his speculations were sober and moderate compared with those of such influential figures as Robert Fludd. Both of these prob. lems have been but scantily explored by historians; but Dr Armitage's incidental descriptions of these matters may at least inform the modern reader that they are there to be studied.

J. R. RAVETZ

\section{OBITUARIES}

\section{Professor H. T. H. Piaggio}

ON June 25 there disappeared from the Nottingham scene a remarkable man who had served the University College and the University of Nottingham from his appointment in 1908 until his retirement in 1950. When I first met him he was professor of mathematics and in his teaching he covered the whole range of the subject to the standard of the University of London honours degree. He was $\mathbf{8 3}$ when he died.
Piaggio organized his life somewhat rigidly in compartments: academic activities, chess at the Mechanics Institute, and social service in connexion with his sister's work for the PDSA. At our first meeting he made it clear that he never accepted social engagements. He was unmarried and lived with his sister, a highly cultured and intelligent woman, until her death a few years ago.

On the research side he was interested in the algebra of invariants, the theory of relativity and the mathematics of psychology. But he will best be remembered for his book, Differential Equations, and his great teaching ability. He told me that as a young lecturer he was very disappointed with his teaching, and that while watching the antics of a cheapjack at Nottingham Goose Fair it suddenly occurred to him that the cheapjack's techniques might be applied to the serious teaching of mathematics, and accordingly he applied them with great success.

$\mathrm{He}$ took keen interest in the welfare of his students. Any unlikely to obtain honours in mathematics were firmly, if gently, shunted into another department; but his good students were carefully tended. Once, when an able woman student was having a poor time in her home, he asked my wife if she would arrange through a women's organization for him to pay the student's fees for residence in a hostel, without disclosing that he was involved. When she agreed, he further asked her to suggest a suitable dress allowance for the student, and this also was secretly passed on.

During the Second World War I saw much of him on the firewatching teams and learned much about him. He bitterly regretted the time which in his youth, for scholarship reasons, he had been forced to spend on the study of classies-particularly Greek-to which he attributed his defective eyesight. He followed to the end of his life a strict diet prescribed for him by a doctor in about 1910 . $\mathrm{He}$ was very keen on chess and organized an international conference in Nottingham in 1938. But, perhaps, even more than chess or mathematical research, he enjoyed reviewing books for Nature, and I am sorry that we shall no longer hear his characteristic half-chuckle.

L. F. Bates

\section{Dr. Carl Kenty}

Carl Kenty, who died at his home in Cleveland Heights, Ohio, on June 10, was a research physicist with the General Electric Company for more than 30 years.

With a B.Sc. from Dalhousie and a Ph.D. from Princeton he first worked at Princeton under K. T. Compton on electron-positive ion recombination in what would now be called a decaying plasma. In 1929 he joined the General Electric Company, where his technical work was devoted to the development of gaseous discharge light sources-lamps of the "illuminated sign" type. He obtained more than fifteen patents in this field. Other more purely scientific work consisted of a series of investigations in gaseous electronics, many centred on the "active nitrogen" problem. Other investigations were a sequel to his work at Princeton, and there was also a group of experiments in which he pioneered into the medium pressure region, from the low pressure area, using inert gases, mercury, nitrogen and various metal vapours, particularly thallium. He was not content with merely recording the beautiful and complex effects observed, but used them to obtain data such as mobilities, and to search for new high-lying metastable levels of molecular nitrogen. Towards the end of his life he returned, among other work, to investigate the persistence of fine dust in plasmas.

Kenty's demonstrations of basic processes of light production were for many years a highlight of the annual conference on gaseous electronics held at various cities in the United States. He was also a fellow of the American Physical Society, past president of the Cleveland Physies Society and a member of the Ohio Academy of Sciences. 